\title{
DNA Base Composition, Flagellation and Taxonomy of the Genus Rhizobium
}

\author{
BY J, DE LEY \\ Laboratory for Microbiology, Faculty of Sciences, State University, \\ Ghent, Belgitum \\ AND A. RASSEL \\ Laboratory for Electron Microscopy, Station for Agricultural Chemistry \\ and Physics, Ministry of Agriculture, Gembloux, Belgium
}

(Received 28 March 1985)

\section{SUMMARY}

There is a correlation between the bese composition of pure DNA from 85 strains of Rhizobium and their type of flagellation. There are two groups of Rhizobia. The peritrichously flagellated organisms, which usually grow fast, have a low \% (guanine + cytosine) composition in the range $58 \cdot 6-63 \cdot 1 \%$; these organisms oecur in all cross-inoculation groups investigated. From a comparison with literature data it appesrs that this group is constituted by two subgroups: Rhizobium leguminosarum and $R$. meliloti. The subpolarly flagellated, slow-growing strains have a somewhat higher (guanine + cytosine) content, mostly in the range $62.8-65.5 \%$; these organisms appear to be specialized mainly for the lupin, soybean, cowpen, Lotus, Wistaria and Robinia groups, It is proposed that only one genetic species is involved, to be called Rhizobium japonicum. The rhizobia would thus contain only three genetic species. The relationship between the high and low (guanine + cytosine) groups is stressed by their closely related $\%(\mathrm{G}+\mathrm{C})$ values, the near-identity of the average compositional distribution of the DNA molecules and because the peritrichous organisms not infrequently show a subpolar flagellum.

\section{INTRODUCTION}

It is well established that the knowledge of the base composition (expressed as molar percentage of guanine + cytosine) of pure DNA will considerably improve and clarify the present bacterial classification.

The present paper is a contribution towards an improved classification of the rhizobia along these lines. The present classification (Bergey's Manthal, 1957) of these bacteria is still based on the cross-inoculation groups proposed by Fred, Baldwin \& McCoy (1932). Many author have expressed dissatisfaction with this system (see Discussion) and one can expect that a future classification will look different. During the course of our work it was noticed that there is a distinct correlation between the average molar (guanine + cytosine) content $(\%(G+C)$ ) and the type 
of flagellation. The conclusion which emerged from it agrees remarkably well with the principle of the proposal recently made by Graham (1964), although in the latter case an entirely different approach was made, namely by Adansonian analysis.

\section{METHODS}

Organisms used. All strains with a number of two or three symbols were obtained through the courtesy of Prof. Ch. Bonnier, Chair of Biochemistry and Microbiology, Institut Agronomique de l'Etat, Gembloux, Belgium. All other strains were obtained through the courtesy of Dr L. W. Erdman, U.S.D.A., Beltsville, Md., U.S.A. Upon receipt, and later during the experiments proper, all strains were checked for bacteriological purity.

Growth conditions. Mass cultures were prepared by growing the organisms for 2-3 days at $25^{\circ}$ in Roux flasks with $150 \mathrm{ml}$. of a modified medium of Ashby (1907) containing (in $\%, \mathrm{w} / \mathrm{v}$ ) 1 mannitol, $0.02 \mathrm{NaCl}, 0.05 \mathrm{~K}_{2} \mathrm{HPO}_{4}, 0.02 \mathrm{MgSO}_{4} .7 \mathrm{H}_{2} \mathrm{O}$, $0.01 \mathrm{CaSO}_{4} .2 \mathrm{H}_{2} \mathrm{O}, 0.01 \mathrm{CaCO}_{3}, 0.1$ yeast extract, 2.5 agar. The organisms were harvested; they were washed by repeated suspending in $0.15 \mathrm{M}-\mathrm{NaCl}, 0 \cdot 1 \mathrm{M}-\mathrm{EDTA}$ buffer $\mathrm{pH} 8$ and centrifuging for $30 \mathrm{~min}$. at $18,000 \mathrm{~g}$. Care was taken to remove as much as possible of the polysaccharides.

Preparation and thermal denaturation of pure $D N A$. The centrifuged cell paste was quickly frozen by immersion of the container in a bath at $-30^{\circ}$ and lyophilized overnight. It was found that this procedure resulted in an improved cell breakage and release of DNA in the preparation proper. DNA was purified according to the procedure of Marmur (1961). The molecular weights of the samples were determined in the Spinco model $\mathbf{E}$ analytical ultracentrifuge and found to be in the range 10-18 $\times 10^{6}$. Thermal denaturation was determined by automatic registration as previously described (De Ley \& Van Muylem, 1963). $T_{m}$, the mid-point of the absorbance-temperature curve, was determined and the average molar (guanine + cytosine) content was calculated with the formula $0.41[\%(\mathrm{G}+\mathrm{C})]=T_{m}-69 \cdot 3$ (Marmur \& Doty, 1962). We have previously checked this formula by plotting $T_{m}$ against direct estimations of \% $(\mathrm{G}+\mathrm{C})$ (De Ley \& Schell, 1963) and found it to be quite satisfactory. All results in Table 1 were calculated with this formula. If the calculations of Colwell \& Mandel (1964) were followed, the $\%(\mathrm{G}+\mathrm{C})$ would be $4-4.4 \%$ lower. The standard deviation $\sigma$ of the compositional distribution around the average $\%(\mathbf{G}+\mathbf{C})$ was calculated from the same absorbance-temperature curve (Doty, Marmur \& Sueoka, 1959).

Flagella staining. The organisms were grown on agar slants with the modified Ashby medium, containing $1 \mathrm{ml}$. of distilled water in the bottom (Rhodes, 1958). After several days at room temperature a loopful of the liquid was suspended gently in water; $35 \%$ formalin was added to make a final concentration of 5-10\%. The organisms were centrifuged for 5 min. at 3000 r.p.m. and repeatedly washed by suspending in water and centrifuging at the same speed. A drop of the final suspension (about $10^{7}-10^{8}$ cells per ml.) was applied on a perfectly clean microscope slide and dried (Leifson, 1960). The staining procedure of Rhodes (1958) was followed.

Electron microscopy. The organisms were grown in liquid medium in Kohl flasks and incubated at $20^{\circ}$. Every $48 \mathrm{hr}$ a sample was taken in the following way: 200- 
mesh grids covered with a $200 \AA$ thick Formvar film were floated on the surface for $30 \mathrm{~min}$. They were then deposited for $30-120 \mathrm{sec}$. on a $2 \%$ phosphotungstic acid solution, pH 5-7 (Brenner \& Horne, 1959; Valentine \& Horne, 1962). They were washed for 15 sec. in distilled water and dried in the air in Petri dishes. A Philips EM 200 electron microscope was used. Photographs were taken on Ilford 9B II and enlargements made on Gevarto 8.

\section{RESULTS}

The results are compiled in Table 1.

Table 1. Base composition, expressed as $\%(G+C)$, 'melting points' $T_{m}$ values, standard deviation $\sigma$ of the compositional distribution about the mean $\%(G+C)$ of purified DNA, and type of flagellation of several Rhizobium strains

\begin{tabular}{|c|c|c|c|c|c|}
\hline Strain no. & Host plant & $\underset{\text { in }}{T_{n}^{\circ} \mathrm{C}}$ & $\%(\mathbf{G}+\mathbf{C})$ & $\sigma$ & $\begin{array}{c}\text { Cross-inoculation } \\
\text { group }\end{array}$ \\
\hline \multicolumn{6}{|c|}{ Peritrichous } \\
\hline 6.2 & Lupinus luteus & $93 \cdot 6$ & $59 \cdot 1$ & $1 \cdot 18$ & Lupin \\
\hline 8но t 19 & Pisum arvense & $93 \cdot 85$ & $59 \cdot 7$ & $0 \cdot 44$ & Pea \\
\hline 14.1 & Vigna sinensis & 93.9 & $59 \cdot 9$ & $0 \cdot 12$ & Cowpea \\
\hline 5.62 & Trifolium repens & $94 \cdot 1$ & $60 \cdot 4$ & 0.0 & Clover \\
\hline $316 \mathrm{ml}$ & Strophostyles pauciflora & $94: 15$ & 60.5 & 0.06 & Strophostyles \\
\hline 9.5 & Phaseolus vulgaris & $94 \cdot 2$ & $60 \cdot 6$ & 0.0 & Bean \\
\hline $301 \times 3$ & Trifolium dubium & $94 \cdot 2$ & $60 \cdot 6$ & $0 \cdot 49$ & Clover \\
\hline $3 \mathrm{EOb5}$ & Lotus americanus & $94 \cdot 2$ & $60 \cdot 6$ & $\mathbf{0} \cdot \mathbf{0}$ & Lotus \\
\hline 5.0 & Trifolium pratense & $94 \cdot 4$ & $61 \cdot 1$ & 0.25 & Clover \\
\hline $3 F 6 g 2$ & Caragana arborescens & $94 \cdot 5$ & $61 \cdot 3$ & 0.75 & Caragana \\
\hline $316 \mathrm{c10}(\mathrm{a})$ & Phaseolus vulgaris & $94 \cdot 55$ & $61 \cdot 4$ & $0 \cdot 06$ & Bean \\
\hline $3 \mathrm{c2nl}$ & Lupinus densiflorus & $94 \cdot 7$ & $61 \cdot 8$ & $0 \cdot 25$ & Lupin \\
\hline 10.0 & Arachis hypogea & $94 \cdot 7$ & $61 \cdot 8$ & 0.0 & Cowpea \\
\hline 11.1 & Vicia sativa & $94 \cdot 8$ & $62 \cdot 1$ & 0.38 & Pea \\
\hline 9.14 & Phaseolus vulgaris & $94 \cdot 9$ & $62 \cdot 3$ & $0 \cdot 63$ & Bean \\
\hline $300 a 30$ & Medicago sativa & $94 \cdot 9$ & $62 \cdot 3$ & 0.0 & Alfalfa \\
\hline $3 \mathrm{FBCl}$ & Wistaria frutescens & $95 \cdot 0$ & $62 \cdot 5$ & 0.88 & Wistaria \\
\hline 1.5 & Medicago sativa & $95 \cdot 0$ & 62.5 & 0.60 & Alfalfa \\
\hline 4.1 & Pisum satioum & $95 \cdot 0$ & $62 \cdot 5$ & $0 \cdot 12$ & Pea \\
\hline $3 F 4 b 7$ & Robinia pseudoacacia & $95 \cdot 2$ & $63 \cdot 1$ & 0.50 & Robinia \\
\hline \multicolumn{6}{|c|}{ Subpolar } \\
\hline $312 b 1$ & Erythrina indica & $94 \cdot 6$ & $61 \cdot 6$ & $0 \cdot 0$ & Cowpea \\
\hline $314 a 8$ & Pueraria thunbergiana & $95 \cdot 1$ & $62 \cdot 8$ & $0 \cdot 87$ & Cowpea \\
\hline 3.9 & Soja hispida & $95 \cdot 2$ & $63 \cdot 1$ & $0 \cdot 63$ & Soybean \\
\hline $3 \mathrm{c} 2 \mathrm{k4}$ & I.upinus sp. & $95 \cdot 3$ & $63 \cdot 3$ & 0.36 & Lupin \\
\hline 10.1 & Arachis hypogea & $95 \cdot 3$ & $63 \cdot 3$ & 0.5 & Cowpea \\
\hline 316 n 10 & Vigna sinensis & $95 \cdot 3$ & $63 \cdot 3$ & 0.37 & Cowpea \\
\hline 3.15 & Soja hispida & $95 \cdot 4$ & $63 \cdot 5$ & 0.38 & Soybean \\
\hline $3 \mathrm{c3al}$ & Ulex europaeus & $95 \cdot 5$ & $63 \cdot 8$ & 0.48 & Cowpea \\
\hline 3.23 & Soja hispida & $95 \cdot 5$ & $63 \cdot 8$ & $0 \cdot 12$ & Soybean \\
\hline 3.14 & S. hispida & $95 \cdot 5$ & $63 \cdot 8$ & $0 \cdot 38$ & Soybean \\
\hline 3I 1 в 59 & S. hispida & $95 \cdot 6$ & $64 \cdot 0$ & 0.96 & Soybean \\
\hline 3.1 & S. hispida & $95 \cdot 6$ & $64 \cdot 0$ & $0 \cdot 36$ & Soybean \\
\hline 3F 3d & Wistaria speciosa & $95 \cdot 7$ & $64 \cdot 3$ & 0.62 & Wistaria \\
\hline 3.2 & Soja hispida & $95 \cdot 9$ & $64 \cdot 8$ & $0 \cdot 0$ & Soybean \\
\hline 1 в 0 a 2 & Albizzia julibrissin & $96 \cdot 2$ & $65 \cdot 5$ & $1 \cdot 0$ & Cowpea \\
\hline
\end{tabular}

Flagellation. The strains from the Beltsville collection were selected because their type of flagellation is known (Leifson \& Erdman, 1958). Several of them were 
rechecked and the type of flagellation was confirmed. The strains of the Gembloux collection were studied both by electron microscopy and by ordinary staining. The latter procedure yields less reliable results because the flagella are easily detached. This appears to happen during the drying of the drop containing the live bacteria. The use of formalin improves the results. Electron microscopy is preferable.

There are two types of strains: peritrichously (Fig. 1) and subpolarly (Fig. 2) flagellated. This confirms previous observations (Hansen, 1919; Löhnis \& Hansen, 1921; Shunk, 1921; Leifson \& Erdman, 1958). Several peritrichously flagellated strains, such as 5.62 from Trifolium repens (Fig. 3), 5.0 from Trifolium dubium and 11.1 from Vicia sativa, are surrounded by fimbriae. We are not aware that these structures have previously been observed in rhizobia.

The peritrichous organisms bear 2-5 flagella, dispersed all over the cell. Quite often one of these flagella is subpolarly implanted. There appears to be a difference between the subpolar and the peritrichous flagella of the same cell since the latter are very easily detached. In several strains only careful inspection reveals the peritrichous individuals amongst an excess of apparently subpolarly flagellated cells, which frequently still have short stumps of broken-off peritrichous flagella. This phenomenon may give rise to erroneous conclusions, e.g. such as the one by Krassilnikov (1959) that all rhizobia have polar flagella. It is also possible that peritrichous strains indeed contain a number of subpolar individuals, a situation which exists, for example, in several acetic acid bacteria (Asai, Iizuka \& Komagata, 1964).

$D N A$ base composition. All strains have a $T_{m}$ in the narrow range $93 \cdot 6^{\circ}-96 \cdot 2^{\circ}$ and $\mathrm{a} \%(\mathrm{G}+\mathrm{C})$ between $59 \cdot 1$ and 65.5 . The peritrichous organisms have the lowest $\%(G+C)$, ranging from $59 \cdot 1$ to $63 \cdot 1$; nearly all the subpolarly flagellated strains are in the upper range from $62 \cdot 8$ to 65.5 (except strain $3 \mathrm{I} 2 \mathrm{~B} 1$, which has $61.6 \%$ ). Both groups are not sharply separated; there is overlapping in the range $61 \cdot 6$ $63.1 \%(G+C)$. The compositional distribution $\sigma$ of the DNA molecules for both groups is nearly identical: these values range from 0 to 1.2 with an average of 0.3 for the peritrichous strains and of $\mathbf{0 . 4 6}$ for the subpolar ones.

\section{DISCUSSION}

The classification within the genus Rhizobium. In the first generally accepted system Fred et al. (1932) proposed 16 cross-inoculation groups. Six of them were elevated to species level: $\boldsymbol{R}$. meliloti (alfalfa), $\boldsymbol{R}$. trifolii (clover), $\boldsymbol{R}$. leguminosarum (pea), R. phaseoli (bean), R. lupini (lupin), and R. japonicum (soybean); the other groups did not receive species status. This is the origin of the species differentiation in Bergey's Manual (1957) and in Prévot's Traité (1961). Krassilnikov (1959) added another four species to them. Later the number of cross-inoculation groups was increased to 22 (Allen \& Allen, 1947). However, innumerable exceptions show that a better system of classification is required (Wilson, 1939, 1944; Johnson \& Allen, 1952; Bonnier, 1958; Lange, 1961; Manil, 1963; Graham, 1964).

$A$ new system of classification. Graham (1964) proposed, after Adansonian analysis, that there would be only three species of rhizobia: the fast-growing Rhizobium meliloti and $\boldsymbol{R}$. leguminosarum (a pool of $\boldsymbol{R}$. leguminosarum, $\boldsymbol{R}$. trifolii and $\boldsymbol{R}$. phaseoli from Bergey's Manual) and the slow-growing Phytomyxa japonicum (a 
renamed pool of $R$. lupini, R. japonicum and organisms from the cowpea group). Our results likewise advocate a renewal in the classification of the rhizobia and they are in agreement with the basic aspects of Graham's proposal. The following facts are new: (1) there is a distinct correlation between the DNA base composition and the type of flagellation: the peritrichous organisms have a low $\%(\mathbf{G}+\mathbf{C})$ and the subpolarly flagellated ones have a high $\%(G+C) ;(2)$ within each group the $\%(\mathbf{G}+\mathbf{C})$ range is very narrow, indicating that the organisms are genetically closely related; $(3)$ the $\%(G+C)$ of both groups are close together and even overlap, an argument in favour of their close genetic relatedness.

The basis for the new classification may be summarized as follows:

(a) The fast-growing, peritrichous, low $(G+C)$ group. This group coincides with Rhizobium leguminosarum and $R$. meliloti of Graham (1964). This finer distinction between species cannot be detected by the method of DNA base composition, because all strains have $\%(G+C)$ which are very close together. $R$. leguminosarum has a $\%(\mathbf{G}+\mathbf{C})$ from $59 \cdot 1$ to $63 \cdot 1$. Both strains of $R$. meliloti are in the vicinity of $62.4 \%$. Organisms of the leguminosarum type have been isolated from almost all host plants and they thus belong to almost all cross-inoculation groups. Our results on the peritrichous flagellation of the alfalfa, clover, pea and bean groups are in perfect agreement with previous reports by Hansen (1919), Löhnis \& Hansen (1921), Shunk (1921), Müller \& Stapp (1925) and Leifson \& Erdman (1958). Several of the other smaller groups are likewise peritrichously flagellated (Leifson \& Erdman, 1958; Leifson, 1960). Table 1 shows this also to be the case for bacteria isolated from the Lotus, Strophostyles, Robinia, Caragana and Wistaria groups.

(b) The slow-growing, subpolarly flagellated, high $(G+C)$ group. This group coincides with Phytomyxa japonicum from Graham (1964). Their base composition is in the range 62.8-65.5, except for an aberrant strain $312 \mathrm{~B} 1$ which has $61 \cdot 6 \%$. Organisms of this type have been mainly isolated from plants of the lupin, soybean and cowpea groups; a few subpolar strains from Wistaria, Lotus and Robinia are known. Both the results from the present paper and from Graham (1964) favour the view that only one genetic group is involved. Whether it is a species of Rhizobium, to be called R. japonicum, or a separate genus, to be called Phytomyxa japonicum, can only be decided unbiasedly after DNA-hybridization experiments.

(c) Arguments for the close genetic relatedness of both groups. (i) $\mathrm{Their} \%(\mathrm{G}+\mathrm{C})$ are very near and even overlap. The compositional distribution $\sigma$ of their DNA molecules is small and of the same order.

(ii) Similarities in morphology and root-nodule-forming properties.

(iii) Frequently peritrichous strains bear a more firmly attached subpolar flagellum.

(iv) The Adansonian similarity is of the order of $80 \%$ (Graham, 1964).

(v) R. Balassa (Balassa, 1963) demonstrated exchange of genetic material by transformation between strains of the alfalfa, lupin and soybean groups.

(vi) Plants of the lupin, soya, cowpea and some of the minor groups are a host to both peritrichous and subpolar strains. This is exemplified in the present paper by strains 6.2, $3 \mathrm{C} 2 \mathrm{nl}$ and $3 \mathrm{c} 2 \mathrm{k} 4$ from Lupinus, $10 \cdot 0$ and $10 \cdot 1$ from Arachis, 14.1 and $316 \mathrm{n} 10$ from Vigna, $3 \mathrm{~F} 3 \mathrm{cl}$ and $3 \mathrm{~F} 3 \mathrm{~d}$ from Wistaria. Similar situations have been encountered by Wilson (1917), Fred \& Davenport (1918), Löhnis \& Hansen (1921), Shunk (1921), Müller \& Stapp (1925) and Leifson \& Erdman (1958). The peritrichous 
organisms can grow in a wide variety of leguminous plants, whereas the subpolar ones are much more narrowly specialized and limited to plants of the lupin, soybean, cowpea and some of the minor groups (Lotus, Wistaria, Robinia).

One of us (J.D.L.) is indebted to the Fonds voor Collectief Fundamenteel Wetenschappelijk Onderzoek for a research and personnel grant as well as to his senior assistant Dr K. Kersters for assistance with the flagella staining. Both authors are indebted to Prof. Ch. Bonnier and Dr L. W. Erdman for providing the strains.

\section{REFERENCES}

Allen, O. N. \& Allen, E. K. (1947). A survey of the nodulation among leguminous plants. Proc. Soil Sci. Soc. Am. 12, 203.

Asal, T., Irzuka, H. \& Komagata, K. (1964). The flagellation and taxonomy of genera Gluconobacter and Acetobacter with reference to the existence of intermediate strains. J. gen. appl. Microbiol. 10, 95.

Ashry, S. F. (1907). Some observations on the assimilation of atmospheric nitrogen by a free living soil organism-Azotobacter chroococcum of Beyerinck. J. agric. Sci., Camb. $2,35$.

Balassa, G. (1963). Genetic transformation of Rhizobium: a review of the work of R. Balassa. Bact. Rev. 27, 228.

Bergey's Manual of Determinative Bacteriology (1957). Ed. by R. S. Breed, E. G. D. Murray and N. Smith. Baltimore: Williams and Wilkins Co.

Bonnier, Сн. (1958). La spécificité dans la symbiose Rhizobium-légumineuses. Antonie van Leeurvenhoek, 24, 1.

Brenner, S. \& Horne, R. W. (1959). A negative staining method for high resolution electron microscopy of viruses. Biochim. biophys. Acta, 34, 103.

Colwell, R. R. \& MaNdel, M. (1964). Adansonian analysis and composition of some Gram-negative bacteria. J. Bact. 87, 1412.

De Ley, J. \& Scheld, J. (1963). Deoxyribonucleic acid base composition of acetic acid bacteria. J. gen. Microbiol. 33, 243.

De Lex, J. \& van Muxlem, J. (1963). Some applications of deoxyribonucleic acid base composition in bacterial taxonomy. Antonie van Leeurvenhoek, 29, 344.

Doty, P., Marmur, J. \& Sueoka, N. (1959). The heterogeneity in properties and functioning of deoxyribonucleic acids. Brookhaven Symp. Biol. 12, 1.

Fred, E. B., Baldwin, I. L. \& McCoy, E. (1932). Root nodule bacteria and leguminous plants. Univ. Wisc. Stud. Sci. no. 5.

Fred, E. B. \& Davenport, A. (1918). Influence of reaction on nitrogen-assimilating bacteria. J. agric. Res. 14, 317.

Graham, P. H. (1964). The application of computer techniques to the taxonomy of the root-nodule bacteria of legumes. J. gen. Microbiol. 35, 511.

HANSEN, R. (1919). Note on the flagellation of the nodule organism of the Leguminosae. Science, 50, 568.

Johnson, M. D. \& Allen, O. N. (1952). Nodulation study with special reference to strains isolated from Sesbania species Antonie van Leeurvenhoek, 18, 13.

Krassilnikov, N. A. (1959). Diagnostik der Bakterien und Actinomyceten. Jena: VEB. Gustaf Fischer Verlag.

LANGE, R. T. (1961). Nodule bacteria associated with the indigenous leguminosae of South-Western Australia. J. gen. Microbiol. 26, 351.

LeIrson, E. (1960). Atlas of Bacterial Flagellation. New York: Academic Press.

LeIfson, E. \& Erdman, L. W. (1958). Flagellar characteristics of Rhizobium species. Antonie van Leeurvenhoek, 24, 97.

Lönnis, F. \& HANSEN, R. (1921). Nodule bacteria of leguminous plants. J. agric. Res. 20, 543. 

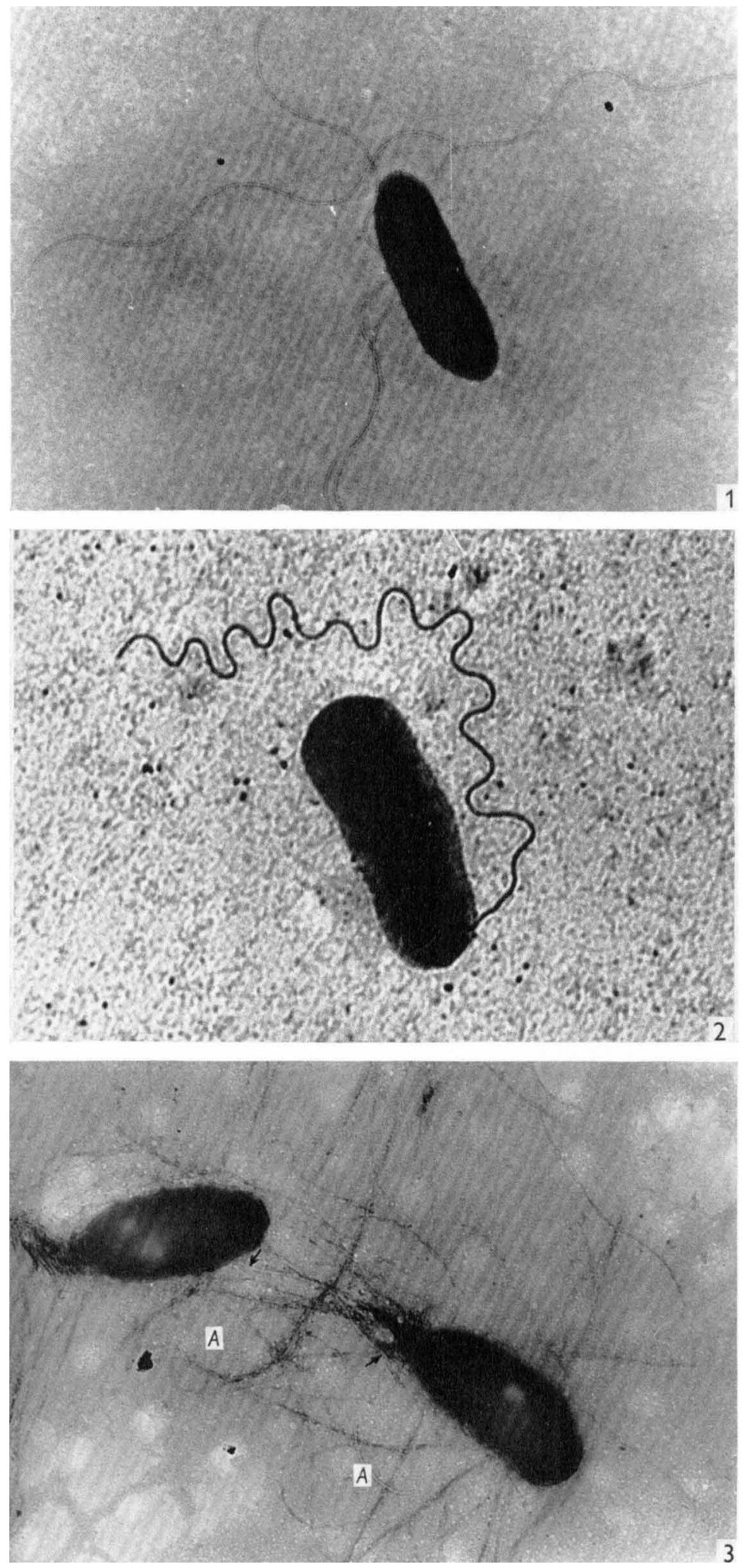
Manil, P. (1963). Les Rhizobium et la fixation symbiotique de l'azote. Ann. Inst. Pasteur, 104, 19.

MARMUR, J. (1961). A procedure for the isolation of deoxyribonucleic acid from microorganisms. J. mol. Biol. 3, 208.

Marmur, J. \& Doty, P. (1962). Determination of the base composition of deoxyribonucleic acid from its thermal denaturation temperature. J. mol. Biol. 5, 109.

MülleR, A. \& STapP, C. (1925). Beiträge zur Biologie der Leguminosenknöllchenbakterien mit besonderer Berücksichtigung ihrer Artverschiedenheit. Arb. Biol. Reichsanst. Land-. u. Forstw. 14, 455.

Prévot, A. R. (1961). Traité de Systématique Bactérienne, Paris: Dunod.

Rhodes, M. E. (1958). The cytology of Pseudomonas species as revealed by a silverplating staining method. J. gen. Microbiol. 18, 639.

SHuNK, I. V. (1921). Notes on the flagellation of the nodule bacteria of Leguminosae. J. Bact. 6, 239.

VAlentine, R. C. \& Horne, R. W. (1962). An assessment of negative staining techniques for revealing ultrastructure. In The Interpretation of Ultrastructure. Ed. by R. J. C. Harris. Symp. int. Soc. Cell Biol. $1,263$.

Wilson, J. K. (1917). Physiological studies of the Bacillus radicicola of the soybean and of the factors influencing nodule production. Bull. Cornell Univ. agric. Exp. Stn, no. 386, p. 369.

WIrson, J. K. (1939). Symbiotic promiscuity in the leguminosae. Trans. Third Comm. Intern. Soc. Soil Sci A, p. 49.

Wilson, J. K. (1944). Over five hundred reasons for abandoning the cross-inoculation groups of the legumes. Soil Sci. 58, 61.

\section{EXPLANATION OF PLATE}

Fig. 1. Electron micrograph of a peritrichously flagellated cell of a Rhizobium, strain 10.0 from Arachis hypogea $(22,200 \times)$.

Fig. 2. Electron micrograph of a subpolarly flagellated cell of a Rhizobium, strain 3.15 from Glycine hispida $(39,500 \times)$.

Fig. 3. Fimbriated cells from a Rhizobium, strain 5.62 from Trifolium repens. Fragments of flagella $(A)$ may be seen $(30,000 \times)$. 